\title{
Analysing Social Capital and Product Innovativeness in the Relationship Evolution of Born-Global Companies the Mediating Role of Knowledge Acquisition
}

\author{
Manuela Presutti $^{1}$ • Giuseppe Cappiello ${ }^{1}$ - Martin Johanson ${ }^{2,3,4}$
}

Published online: 18 April 2020

(C) Springer Science+Business Media, LLC, part of Springer Nature 2020

\begin{abstract}
Relatively little is known about how born-global companies (BGs) innovate abroad during their lifecycle or about how the international innovation activities of BGs are related to their social capital. The network concepts of relational, structural, and cognitive social capital are almost completely neglected in the international business literature on BGs' innovation activities according to a dynamic approach. The aim of this research is to study the direct and indirect effects of structural, cognitive and relational social capital on BGs' product innovation by including the mediating role of market and technological knowledge acquisition. We develop a set of hypotheses that we combine and test in a structural equation model. We provide results with theoretical and practical implications for BGs in terms of both social capital and innovation abroad.
\end{abstract}

Keywords Born globals · Foreign customer relationships · Innovation · Social capital · Knowledge acquisition

\section{Introduction}

Born-global companies (BGs) are young firms that begin to internationalize soon after inception and do so at a high speed (Knight and Cavusgil 2005; Baronchelli and Cassia 2014). From the extant literature on BGs (Johanson and Vahlne 2003, 2009; Oviatt and

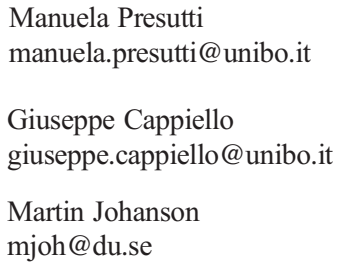

Extended author information available on the last page of the article 
McDougall 1994, 2005), we have little knowledge about the dynamic interaction between the social capital and foreign innovation of BGs (Agndal et al. 2008; Coviello 2006; Prashantham and Birkinshaw 2015).

This gap is particularly critical given the considerable disagreement among scholars about the importance of particular social capital configurations (structural, relational and cognitive) for the foreign innovation activity of BGs (Freeman et al. 2006). Moreover, the different configurations of social capital demand different types of effort and resources during the evolution of BGs over time (Starkey and Tempest 2010; Zahra et al. 2009).

As suggested in previous studies (Hugo Baier-Fuentes et al. 2019; Pirolo and Presutti 2010), this lack of consensus persists because a large majority of studies on this topic have not followed a dynamic approach, while the impact of social capital on BGs' innovation activity abroad (Hohenthal et al. 2014) may not be static but rather contingent on several factors, such as the different stages of BGs' lifecycle (Alguezaui and Filieri 2010).

In this research, we first decided to follow a longitudinal approach, conducting our empirical analysis over two different periods of a BG's lifecycle (early stage and emergence) to determine how the interaction between social capital and product innovation can be contingent on the different periods of the BG's lifecycle we analysed. Second, we included knowledge acquisition as a contingent, moderator variable between social capital and the product innovation process during the BG's evolution over time. Following other studies, our unit of analysis is the evolution of relationships between BGs and their key foreign customers (Pirolo and Presutti 2010; Yli-Renko et al. 2001). We study both market and technological knowledge at the same time.

According to these considerations, this paper aims to answer the following interrelated research questions: 1) Does interorganizational social capital evolution have a direct effect on BGs' foreign product innovation activity during different stages of their lifecycle? 2) Is the relationship between the evolution of social capital and BGs' foreign product innovation during their lifecycle mediated by the knowledge acquisition factor?

We empirically verify that the evolution of social capital between BGs and their key foreign customers is positively related to knowledge acquisition, both market and technological, which in turn influences the BG's innovation. Any direct effects between social capital and product innovation are found in this research. At the same time, all three dimensions of social capital have a direct positive and significant effect on the BGs' innovation process abroad. It means that first, having international relationships characterized by strong social capital seems to be fruitful for learning and innovation, as the negative aspects of over-embeddedness are not verified in this research; second, these results highlight the essential role of knowledge as a key mechanism by which interorganizational foreign customers' collaborations can be leveraged by a BG during its lifecycle to reinforce its innovativeness abroad.

This study, which introduces a dynamic perspective in the study of social capital, innovation and knowledge acquisition for a BG firm, makes several theoretical and managerial contributions to the international entrepreneurship literature, social capital theory, and knowledge acquisition issues, which will be discussed in depth in the final sections of the paper (Falk and de Lemos 2019). 
The paper is structured as follows. First, we present the theoretical context of the research, and we then justify and formulate the hypotheses. We subsequently describe the empirical analysis and the methods applied and then present the findings. This is followed by a discussion in which we analytically present the theoretical and managerial implications. The final section discusses the limitations of the study and offers research questions for the future.

\section{Theoretical framework}

A BG is generally defined as a "business organization that, from or near [its] founding, seeks superior international business performance from the application of knowledgebased resources to the sale of outputs in multiple countries" (Knight and Cavusgil 2005 , p. 7). In the last two decades, BGs have changed how they undertake innovation activities, more widely involving their customer relationships and using their external networks to acquire knowledge than can be applied in product innovation, the dominant mode of innovation aiming primarily at improving product performance. Foreign product innovation is a continuous and cross-functional process involving and integrating a growing number of different competencies inside and outside organisational boundaries.

At a general level, international entrepreneurship proposes that the embeddedness of relationships in social and business networks with foreign customers is a factor reinforcing the product innovation activity of BGs (Andersson et al. 2016; Bell et al. 2001).

Within this framework, social capital has received extensive research attention in the past several decades, including in the case of companies operating abroad, as confirmed by many studies of international entrepreneurship based on BGs (Coviello 2006). Social capital is a multidimensional and multilevel concept that represents resources or assets rooted in an individual's or in a group's network of social relations (Bika and Kalantaridis 2017; García-Villaverde et al. 2018).

For our purposes, we adopt the Nahapiet and Ghoshal (1998) definition of social capital as "the sum of the actual and potential resources embedded within, available through, and derived from the network of relationships possessed by an individual or social unit" (p.243). As a set of resources and relationships, social capital has different attributes, categorized into the following three dimensions (Nahapiet and Ghoshal 1998): structural, relational, and cognitive. While the structural dimension refers to the network structure, the relational and cognitive dimensions focus on the content of the relationships (Ado et al. 2017). Despite being separately identified with distinct facets, the three dimensions are highly interrelated. Specifically, the structural dimension refers to social capital as the social network of relationships; its features include network ties and network configuration (Zhao and Hsu 2007). According to the authors, it refers to the "overall pattern of connections between actors" or "who you can reach and how you can reach them" (pp.244), and its most important facets are the presence or absence of network ties, the network configuration, and the pattern of linkages in terms of density, connectivity, and hierarchy. Relational social capital refers to the assets rooted in relationships, such as 
trust, trustworthiness, sanctions, norms, expectations, obligations, identity and identification (Pérez-Luño et al. 2011). This dimension refers to those "assets created and leveraged through relationships" (p.244) and the history of interactions. Finally, the cognitive dimension reflects the common understandings that consist of shared codes and language and shared narratives. It captures the public good aspect of social capital, including a shared vision and common values in an organisation (Presutti and Odorici 2019). According to Nahapiet and Ghoshal (1998, p. 244), this dimension refers to the "resources providing shared representations, interpretations, and systems of meaning among parties".

Although social capital can be studied at different levels of analysis, we adopt the interorganizational viewpoint and focus on the relationships between suppliers (BGs) and their main foreign customers. In the international business literature, these relationships are called "international strategic partnerships," underscoring the firms' joint strategic interest in the partnership's development (Agndal et al. 2008; Gabrielsson et al. 2014; Iturrioz et al. 2015).

In this paper, we analyse the impacts of the different dimensions of social capital on BGs' product innovations by including the moderating role of knowledge acquisition, as we propose that knowledge acquisition occurs through relationships with key customers. This learning results in elements of knowledge of the market in general, for instance, about trends and preferences but also elements concerning the specific relationship from which the knowledge is acquired (Parra-Requena et al. 2015). This is market knowledge acquisition. At the same time, the learning results in elements of knowledge of differentiated technological skills, complementary assets, and organizational routines that are necessary for new product-market entry, innovation, and firm growth, that is, technological knowledge. As a consequence, we contend that a BG's innovation is a result of the firm's management of social capital with its main foreign customers, mediated by external market and technological knowledge acquisition (Freeman et al. 2006).

Moreover, we observe that none of the previous studies link social capital with firms' international innovation activity according to the different steps of a BG evolution (Bembom and Schwens 2018; Chen et al. 2016; Prashantham and Birkinshaw 2015).

Though the validity of the concept of the lifecycle has been debated, its usefulness has repeatedly been verified in many empirical studies (McCann 1991). The main critical point concerns the identification of the duration of the stages, which is unspecified since they may overlap (McGahan Anita et al. 2004). This problem is difficult to solve because the literature offers no guidelines on the length of the period over which smoothing should occur. Although some studies have used subjective measures to identify the stages of a firm's lifecycle using the traditional scale developed by Kazanjian (1988), in this paper, we prefer to use a time approach to identify the different stages of a start-up's lifecycle and their duration (McGahan Anita et al. 2004).

By adopting this view of time (Shepherda et al., 2000), we focus on the following two specific stages of a BG's life cycle: during emergence (from 1 to 3 years) and during the early growth stage (from 7 to 10 years), according to several other studies (Hite 2005; Hite and Hesterly 2001). 


\section{Hypothesis development}

\section{Structural social capital and knowledge acquisition}

In our research, structural social capital refers to the capacity to develop and utilize a variety of profitable relationships to expand into foreign markets. This is a costeffective way to acquire knowledge and resources that are not under the firm's control (Coviello 2006; Eriksson et al. 1997; Uzzi 1997).

We contend that a BG with high structural social capital in its relationships with key foreign customers can better acquire knowledge from them (Adler and Kwon 2002; Yli-Renko et al. 2001). As firms in the key customer's network are indirectly connected with the BG, they can provide information about trends and customer needs in the market (Kim et al. 2011; Presutti and Boari 2008). This knowledge about the network, characterized by high structural social capital, makes it possible to evaluate new technological ideas and opportunities and, when needed, to adapt them to the network. Following these arguments, we posit the following hypothesis:

Hypothesis 1: The greater the structural social capital is between a BG and its key foreign customer from the emergence to the early stage of a BG's lifecycle, the more knowledge acquired in the relationship with the customer in these periods.

\section{Relational social capital and knowledge acquisition}

Relational social capital in the relationship between the BG and its key customers reflects the quality of the specific content of a relationship and is a product of joint experience or a history of interactions. While we recognize that many negative factors have been associated with relational social capital (the dark side of social capital), we maintain that high levels of relational social capital may increase relationship-specific common knowledge, as the greater frequency, breadth, and depth of interactions facilitate the diffusion and transfer of valuable information between business partners (Zahra et al. 2000).

Relational social capital (Nieto and González-Álvarez 2016) thereby leads to high predictability and a belief that the relationship will be maintained, and therefore, the counterparts can make relationship-specific investments and share knowledge and together solve any problems that may occur (Deligianni et al. 2015). Consequently, relationships with high relational social capital promote the acquisition of knowledge. Following these arguments, we posit the following:

Hypothesis 2: The greater the relational social capital is between a BG and its key foreign customer from the emergence to the early stage of a BG's lifecycle, the more knowledge acquired in the relationship with this customer during these periods.

\section{Cognitive social capital and knowledge acquisition}

The cognitive dimension of social capital is represented by the development of common goals and norms and reciprocal expectations concerning the goodwill and 
trustworthiness of the exchange partner (Hagedoorn 2006; Larson 1992; Nahapiet and Ghoshal 1998). Thus, cognitive social capital provides a joint platform to identify and categorize which of the acquired pieces of knowledge are relevant for the specific relationship (Larson 1992; Tsai and Ghoshal 1998).

Moreover, cognitive social capital enhances the reception and understanding of valid knowledge and detailed information from key foreign customers. Finally, we argue that cognitive social capital reduces the risk of reciprocal opportunism and, more generally, lowers transaction costs, allowing business partners to develop reliable and effective communication channels and reducing the uncertainty about economic performance outcomes. Following these arguments, we posit the following:

Hypothesis 3: The greater the cognitive social capital is between a BG and its key foreign customer from the emergence to the early stage of a BG's lifecycle, the more knowledge acquired in the relationship with this customer during the analysed period.

\section{Knowledge acquisition and product innovativeness}

We contend that a BG, through its relationship with its key customer, is able to obtain both general market knowledge, which may also concern other potential customers and suppliers, and cultural and institutional knowledge, which can be linked to the specific product developed by the BG. In addition, as the key customer is expected to use the new product, the BG can offer specific knowledge about technology relevant to the market, which is likely to have a positive impact on product development.

As the knowledge acquired in the relationship with the key foreign customer gives the $\mathrm{BG}$ an idea of how to handle a specific problem, the $\mathrm{BG}$ can establish routines and structures to manage the process of new product development. In line with various works (Coviello and Joseph 2012), we find that the capability of BGs to act in networks to acquire knowledge has a critical influence on innovation. As a BG involves its key customer in product development and interacts with key partners to acquire knowledge, it may perform various types of innovation work. In this light, regardless of how extensive the networks or how well existing relationships are maintained, the interaction is characterized by the identification of shared interests, such as improved efficiency, profit, or value, between suppliers and customers for the purpose of bringing about coordination and cooperation. The interactions in networks also generate trust and cooperation between customers and suppliers (Uzzi 1997). The prevailing trust makes it likely that the BG and its customers will perceive the knowledge acquired and the information exchanged to be of high quality and to be valid for the innovation. Therefore, we postulate the following:

Hypothesis 4 The more knowledge acquired in the relationship with the key foreign customer from the emergence to the early stage of a BG's lifecycle, the more innovative the products developed by the BG during these periods will be. 


\section{Social capital, knowledge acquisition, and product innovativeness}

The first three hypotheses link social capital with knowledge acquisition, and the fourth one links knowledge acquisition with product innovation abroad. The proposed discussion seems to suggest that social capital affects product innovation indirectly through its effects on knowledge acquisition. In practical terms, while social capital provides basic elements for achieving benefits in the foreign relationship of a BG, the internal organizational learning process converts social capital into tangible benefits such as a higher propensity to innovate. Product innovation is contingent on the information and knowledge generated in the exchange of social capital between BGs and their foreign customers. As BGs interact with customers in their international relationships, they acquire knowledge that they can use to reinforce their innovation activity. The foreign product innovation of BGs is partly about maintaining and strengthening their existing relationships with partners in their relational and structural embeddedness and is mainly influenced by the ability to acquire knowledge from relational, social and cognitive social capital relationships (Zhao 2015; Uzzi and Lancaster 2003).

This implies that the main advantage of being embedded in foreign international networks of social capital is the knowledge the BGs can acquire from relationships in the networks (Zahra et al. 2009), which in turn provides a platform for product innovation. Thus, we propose a full mediation effect that is how knowledge acquisition mediates between social capital and foreign product innovation, while the direct effect between social capital and foreign product innovation is not significant. Consequently, we hypothesize the following:

- Hypothesis 5a: Knowledge acquisition in the foreign market's network mediates the relationship between structural social capital and the innovativeness of the products developed by the BG from the emergence to the early stage of a BG's lifecycle.

- Hypothesis 5b: Knowledge acquisition in the foreign market's network mediates the relationship between relational social capital and the innovativeness of the products developed by the BG from the emergence to the early stage of a BG's lifecycle.

- Hypothesis 5c: Knowledge acquisition in the foreign market's network mediates the relationship between cognitive social capital and the innovativeness of the products developed by the BG from the emergence to the early stage of a BG's lifecycle. Table 1 formalizes the research hypotheses, and Fig. 1 describes the hypothesized model.

\section{Material and methods}

\section{Sample and data}

We collected empirical data on a sample of small- and medium-sized high-tech firms located in one of the most important areas in central Italy, the Tiburtina Valley, which is 
Table 1 Research Hypotheses

Hypothesis Sup pos ed Effect

Structural Social Capital on Knowledge Acquisition

H1 +

Relational Social Capital on Knowledge Acquisition

$\mathrm{H} 2+$

Cognitive Social Capital on Knowledge acquisition

H3 +

Knowledge Acquisition on Product Innovativeness

Structural Social Capital on Product Innovativeness via Knowledge

$\mathrm{H} 4+$
Acquisition

Relational Social Capital on Product Innovativeness via Knowledge Acquisition

Cognitive Social Capital on Product Innovativeness via Knowledge Acquisition

H5a +

$\mathrm{H} 5 \mathrm{~b}+$

$\mathrm{H} 5 \mathrm{c}+$

This table shows the research hypotheses with the expected effects

approximately $14 \mathrm{~km}$ from the centre of Rome. This urban high-tech cluster has already been the focus of previous international studies (D'Angelo and Presutti 2019; Presutti et al. 2011). We focused on the electronics sector, which, according to the definition of the National Federation of Electronics Firms, consists of the computer industry, electronics in the strictest sense, and telecommunications.

This sector is characterized by a situation where customers increase their level of market and technological knowledge by acquiring products from suppliers. Thus, for both customers and suppliers, firm knowledge acquisition and product innovation processes depend to a great extent on interactive learning between them. This situation encourages local firms to become increasingly specialized, resulting in strong differentiation in their internal market and technological knowledge bases. The R\&D activity

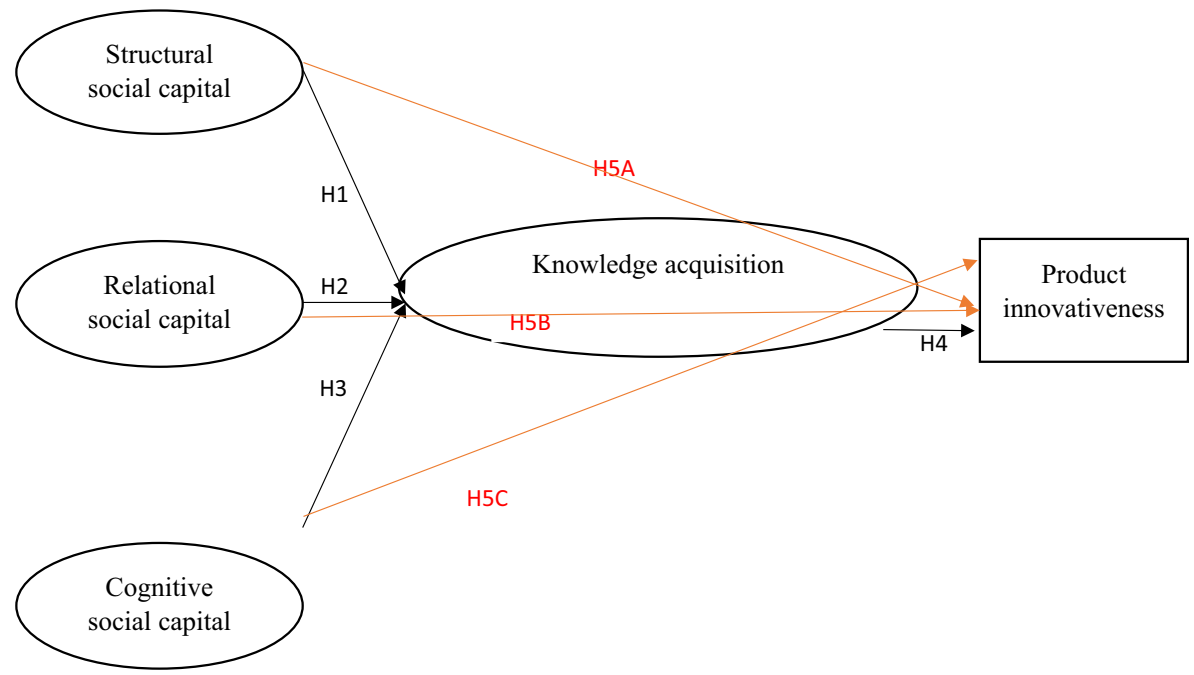

Fig. 1 The Hypothesized Model, This figure shows the model with the different research hypotheses and the relationships among the variables 
and the scope and extent of new products launched by these firms are strongly conditioned by the market and technological knowledge acquired from their customers because new products need to be in line with customers' specific requirements.

We conducted our empirical analysis for two different periods, i.e., the end of 2010 and the end of 2018, to capture the empirical analysis in two different moments of the BGs' lifecycle, i.e., during the emergence stage (from 1 to 3 years of age) and during the early growth stage (from 7 to 10 years of age). First, at the beginning of our data collection (October 2010), we applied the following three criteria following the work of Taylor and Jack (2012) to identify BGs: early internationalization (during their first three years of existence), minimum share of foreign sales as a percentage of total sales over $25 \%$, and international presence in multiple countries.

This process resulted in a total of 150 firms, 82 of which accepted our request for a personal interview to complete the questionnaire. Eight years later, we contacted the same firms, and we found that 70 (of 82) had survived. This high survival rate is not surprising because these firms were granted favourable financial terms by the local incubator and authorities. We obtained responses from 68 (of 70) firms; therefore, we focused only on this subsample of 68 companies in both periods of analysis to compare the results over the BGs' lifecycle.

Although the percentages of both non-respondents and non-surviving firms are very low and statistically non-significant (Churchill 1979), we tested for response bias by checking some secondary data. For the 12 non-surviving firms in the two analysed periods, we considered data until their last year of life, except for 2 firms that failed in less than a year. No significant differences in terms of firm size (average sales or employees) or customer size were found. The results of the statistical tests of response bias suggest that our sample is representative of the population.

Our empirical research focuses on the foreign vertical relationships between these BG start-ups located in the cluster and their main foreign customers. To identify key foreign customers, we followed many previous works (i.e., Pirolo and Presutti 2010; Presutti et al. 2019), giving entrepreneurs the freedom to list the international customers that account for the highest proportion of their foreign sales revenues (Yli-Renko et al. 2001), with a maximum of 10 partners per company (key foreign customers).

The final relational map of the adopted sample is composed of 480 foreign main customers who interviewed entrepreneurs listed during both phases of data collection. The breakdown of key foreign customers by country shows the clear dominance of European customers, i.e., $65 \%$, in both periods, while key foreign customers located in very distant locations represent only approximately $3 \%$ of the total sample.

The data collection process for both analysed periods lasted approximately three months (October-December 2010; October-December 2018). For each period, we completed 120 total hours of interviews. On average, the interviews lasted $20 \mathrm{~min}$. In both periods of observation, we administered a structured questionnaire with Likert scales. Because the questionnaire constitutes the primary data source for this research, when necessary we even conducted third interviews to complete the questionnaire. Thus, we gained a fuller understanding of all the critical points necessary to realize our research goals. We met with the same entrepreneurs at both moments of observation. We completed our dataset by collecting additional, firm-specific information.

Overall, the results show a positive incremental growth path of the BGs during the investigated period. The BGs during the first period were very young (two years on 
average). During the first period, the firms in the sample developed an average of six new products, while in the second period, they introduced 9 products. At the end of 2018 , the total average sales of the BGs amounted to $€ 390,000$, with a growth of $26 \%$ in the analysed periods. The BGs' foreign sales, on average, amounted to $€ 100,000$ in the second period, with a percentage growth of $26 \%$. In both periods, the percentage of foreign sales on total sales was approximately $26 \%$. In addition, the average R\&D expenditure in relation to total sales was $3.5 \%$ at the end of the second period (range $0.01 \%-15 \%$ ). The key foreign customers were older than their suppliers but were similar in terms of size in both periods of analysis. The percentage of sales of key foreign customers on total foreign sales, on average, was $45 \%$ at the end of 2018. Table 2 reports the descriptive statistics for the untransformed variables.

\section{Measures}

The individual measurement items for the study's dependent, independent, and control variables are listed in Table 3; the construction of the measures is explained in the following. All statement-style items were measured on a scale from $1=$ do not agree to $7=$ completely agree. To capture a dynamic perspective, we considered the growth of the values of those items between the periods of observation.

\section{Dependent variable}

Product Innovativeness. We measured innovation activity following the work of Rindfleisch and Moorman (2001). Specifically, four items were used to assess the BGs' opinions about the innovativeness of their products developed as a result of their relationships with their key foreign customers (Table 3).

\section{Independent variable}

Knowledge Acquisition in the Relationship. We measured knowledge acquisition with two statements reflecting the technological and market knowledge that a firm might

Table 2 Descriptive Statistics of the Untransformed Variables (Average Values)

\begin{tabular}{lcc}
\hline & $\mathbf{2 0 1 0}$ & $\mathbf{2 0 1 8}$ \\
\hline Innovation & 6 & 9 \\
Total Sales (€0.000) & 310.10 & 390.20 \\
Foreign Total Sales & 80.00 & 100.00 \\
CustSize (€0.000) & 308.15 & 400.10 \\
'CustAge & 14 & 25 \\
\% of Foreign Sales with Key Customers & $40 \%$ & $45 \%$ \\
FirmAge & 2 & 10 \\
R\&D Expenditure & 2,5 & 3.5 \\
Number of served foreign markets & 4 & 6 \\
\hline
\end{tabular}

This table shows the descriptive statistics of the variables included in the model 
Table 3 Measurement Model

\begin{tabular}{|c|c|c|c|c|c|c|c|}
\hline \multirow{3}{*}{$\begin{array}{l}\text { Factor Name } \\
\\
\text { Structural } \\
\text { Social } \\
\text { Capital }\end{array}$} & \multirow{2}{*}{$\begin{array}{l}\text { Measurement Item } \\
\text { We obtained new contacts (customers, } \\
\text { suppliers and employees) through this } \\
\text { foreign customer. }\end{array}$} & \multicolumn{2}{|c|}{$\begin{array}{l}\text { Stand ardized } \\
\text { Loading } \\
20102018\end{array}$} & \multicolumn{2}{|c|}{$\begin{array}{l}\text { Cronbach's } \\
\text { Alpha }\end{array}$} & \multicolumn{2}{|c|}{$\begin{array}{l}\text { Average } \\
\text { Variance } \\
\text { Extracted }\end{array}$} \\
\hline & & $1.00^{* *}$ & $1.00 * *$ & 0.82 & 0.85 & 0.52 & 0.53 \\
\hline & $\begin{array}{l}\text { This foreign customer has opened the door } \\
\text { to other valuable business partners. } \\
\text { This foreign customer provided us with new } \\
\text { contacts useful to our development. }\end{array}$ & $0.63^{*}$ & $0.61 *$ & & & & \\
\hline \multirow[t]{4}{*}{$\begin{array}{l}\text { Relational } \\
\text { Social } \\
\text { Capital }\end{array}$} & $\begin{array}{l}\text { In this relationship, both sides avoid making } \\
\text { demands that can seriously damage the } \\
\text { interests of the other. }\end{array}$ & $0.60^{* *}$ & $0.64 *$ & 0.85 & 0.87 & 0.53 & 0.58 \\
\hline & $\begin{array}{l}\text { In this relationship, neither side takes } \\
\text { advantage of the other, even if the } \\
\text { opportunity arises. }\end{array}$ & $0.63^{* *}$ & $0.61 * *$ & & & & \\
\hline & $\begin{array}{l}\text { This foreign customer always keeps } \\
\text { promises to us. }\end{array}$ & $1.00 *$ & $1.00 * *$ & & & & \\
\hline & $\begin{array}{l}\text { We consider this foreign customer's order } \\
\text { even if we have not yet received a formal } \\
\text { request. }\end{array}$ & $0.65^{*}$ & $0.66^{*}$ & & & & \\
\hline \multirow{2}{*}{$\begin{array}{l}\text { Cognitive } \\
\text { Social } \\
\text { Capital }\end{array}$} & $\begin{array}{l}\text { We have never been afraid of losing contact } \\
\text { with this foreign customer. }\end{array}$ & $1.00^{*}$ & $1.00^{*}$ & 0.82 & 0.83 & 0.56 & \\
\hline & $\begin{array}{l}\text { We maintain close social relationships with } \\
\text { this foreign customer. } \\
\text { We know this foreign customer's people on } \\
\text { a personal level. }\end{array}$ & $0.76^{* * *}$ & $0.81^{* * *}$ & & & & \\
\hline \multirow[t]{2}{*}{$\begin{array}{l}\text { Knowledge } \\
\text { Acquisition }\end{array}$} & $\begin{array}{l}\text { Because we supply to this foreign customer, } \\
\text { we are able to obtain a tremendous } \\
\text { amount of market and technical } \\
\text { knowledge. }\end{array}$ & $0.66^{* *}$ & $0.69^{*}$ & 0.80 & 0.83 & 0.51 & 0.55 \\
\hline & $\begin{array}{l}\text { We obtain most of our valuable information } \\
\text { on customer needs and trends from this } \\
\text { customer. }\end{array}$ & $0.60^{*}$ & $0.65^{*}$ & & & & \\
\hline \multirow{4}{*}{$\begin{array}{l}\text { Product } \\
\text { Innovative- } \\
\text { ness }\end{array}$} & $\begin{array}{l}\text { The new product/products is/are very novel } \\
\text { in our industry. }\end{array}$ & $1.00 * *$ & $1.00^{*}$ & 0.74 & 0.83 & 0.57 & 0.58 \\
\hline & $\begin{array}{l}\text { The new product/products offers/offer new } \\
\text { ideas in our industry. }\end{array}$ & $0.63 *$ & $0.70^{* * *}$ & & & & \\
\hline & The new product/products is/are creative. & $0.62 *$ & $0.65^{*}$ & & & & \\
\hline & $\begin{array}{l}\text { The new product/products is/are capable of } \\
\text { generating ideas for other products. }\end{array}$ & $0.66^{*}$ & $0.69^{*}$ & & & & \\
\hline
\end{tabular}

$* \mathrm{p}$ value at the $10 \%$ level; **p value at the $5 \%$ level

This table shows the measurement model of all considered variables

acquire from the key customers and information about customer needs and trends in the market. The items were based on Nooteboom et al. 1997 and von Hippel (1988) and have previously been used effectively by several authors (Kogut and Zander 1992; Zahra et al. 2000). 


\section{Structural social capital}

We used multi-item measures to analyse the structural embeddedness between a firm and its key foreign customers because they provide considerable advantages over single-item measures (Churchill 1979). Specifically, we measured structural embeddedness using three items that reflect the degree to which the key foreign customer relationship provides the BGs with a network of new foreign business contacts (Larson 1992; Uzzi 1997; Yli-Renko et al. 2001)

\section{Relational social capital}

We used multi-item measures to analyse the relational social capital between a BG and its key foreign customers because they provide considerable advantages over singleitem measures (Churchill 1979). In line with previous studies (Nahapiet and Ghoshal 1998; Yli-Renko et al. 2001), we selected four items to measure relational social capital.

\section{Cognitive social capital}

For the cognitive dimension, we also used multi-item measures. In line with previous studies (Nahapiet and Ghoshal 1998; Yli-Renko et al. 2001) and based on our definition of the concept, in which we view mutual understanding and shared norms and values based on social interaction, we measured the cognitive dimension of social capital using three items to measure this dimension.

\section{Control variables}

We included several control variables to isolate the effect of the independent variables in the model. First, we consider the level of a BG's international expansion, including international sales as a percentage of total sales in the two periods of observation, as a control variable. We decided to also include the age at internationalization as a control variable that can influence the BG's ability to learn within the customer relationship and influence knowledge acquisition abroad. We included in the model the difference in the percentages of the two values. Moreover, we use $R \& D$ spending (R\&D) as a control variable for a firm's willingness to invest in absorptive capacities that can help it to acquire knowledge from its key foreign customers. Following other recent research on measuring absorptive capacity (e.g., Cohen and Levinthal 1990), this parameter was measured by considering the difference between the log value of the average ratio between R\&D expenditures and total sales during the two analysed periods. Following similar studies (Boschma 2005), we also included geographical proximity as a control variable, which we computed using the natural logarithm of physical distance (in $\mathrm{km}$ ), because we expected relative changes in distance to be more significant than simple, absolute changes. Moreover, we included cultural distance as a control variable by using Simonin's (1999) items to measure how greatly the national culture of foreign customers differs from the BG's national culture (Nooteboom et al., 1997).

Table 4 reports the descriptive statistics of the variables and their correlations in the two analysed periods. 
Table 4 Descriptive Statistics and Correlations (2010-2018)

\begin{tabular}{|c|c|c|c|c|c|c|c|c|c|}
\hline Variables & 1 & 2 & 3 & 4 & 5 & 6 & 7 & 8 & 9 \\
\hline \multicolumn{10}{|l|}{ 1. \% of BG's Foreign Sales } \\
\hline 2. BG's R\&D Spending & 0.08 & & & & & & & & \\
\hline 3 BG's Age at Internationalization & 0.28 & $0.75^{*}$ & & & & & & & \\
\hline 4. Geographical Proximity & $0.10^{*}$ & $0.18^{*}$ & $0.28 *$ & & & & & & \\
\hline 5. Cultural Proximity & 0.10 & 0.09 & $0.18 *$ & $0.65^{*}$ & & & & & \\
\hline 6. Structural Social Capital & 0.29 & 0.12 & 0.69 & 0.15 & $0.22 *$ & & & & \\
\hline 7. Relational Social Capital & 0.81 & 0.28 & 0.18 & 0.27 & 0.12 & $0.34 * *$ & & & \\
\hline 8. Cognitive Social Capital & 0.50 & 0.29 & 0.35 & 0.11 & 0.89 & 0.15 & $0.35 * *$ & & \\
\hline 9. Knowledge Acquisition & 0.30 & 0.10 & 0.18 & 0.30 & 0.62 & $0.33^{* *}$ & $0.18 *$ & $0.74 * *$ & \\
\hline 10. Product Innovativeness & 0.22 & 0.10 & 0.27 & 0.30 & 0.55 & 0.38 & $0.15^{*}$ & $0.44 *$ & $0.13^{*}$ \\
\hline
\end{tabular}

$* \mathrm{p}$ value at the $10 \%$ level; **p value at the $5 \%$ level

This table shows the correlations among the selected variables

\section{Reliability, validity, and Endogeneity}

We took several steps to ensure data validity and reliability. First, we pretested the survey with five BG founders and asked them to closely review the survey. Based on the suggestions we received, we then revised any potentially confusing items. Second, we used previously validated measurement items wherever possible to help ensure the validity of our measures. Third, multiple-item measures were used for most constructs to enhance content coverage. We measured these items on the questionnaire using seven-point Likert scales.

For many critical variables in this study, there are no perfect proxies, so we relied on the opinions of the BG founders; we know that some of the studies' relationships among variables can be affected by common method variance. Thus, relationships among variables may be the result of common method variance, a potentially significant but often overstated issue (Wagner and Crampton 1993). We reduced the potential for common method problems by employing previously validated measures (Spector 1987). We examined the possibility of common method variance via Harman's one factor test for all variables in the study. Significant common method variance would result in one general factor accounting for the majority of covariance in the variables (factor loading equals 1). The analysis resulted in three factors with eigenvalues greater than one, with the first factor accounting for only $29 \%$ of the total variance and the independent and dependent variables loading on different factors. Thus, common method variance is unlikely to be causing the relationships among variables in our research.

Finally, in this study, we also consider the endogeneity problem. In particular, to identify the endogeneity of the explanatory variables, we use the Durbin-Wu-Hausman test (Wooldridge 2006). Table 5 illustrates the test results, which reveal that the three different dimensions of social capital do not suffer from an endogeneity problem when both knowledge acquisition and product innovativeness are used as the dependent variables (Table 5). 
Table 5 Results of the Durbin-Wu-Hausman Test

\begin{tabular}{|c|c|c|c|c|}
\hline & \multicolumn{2}{|c|}{ Knowledge Acquisition } & \multicolumn{2}{|c|}{ Product Innovativeness } \\
\hline & 2010 & 2018 & 2010 & 2018 \\
\hline Structural Social Capital & 185.3 & 186.5 & 129.6 & 129.9 \\
\hline Relational Social Capital & 161.3 & 162.5 & 169.2 & 167.3 \\
\hline Cognitive Social Capital & 167.8 & 165.5 & 168.2 & 169.2 \\
\hline
\end{tabular}

Chi-square values are presented in this table

This table shows the results of the Durbin-Wu-Hausman test

\section{Results}

The hypotheses are tested using a structural equation model based on the covariance matrix (CB-SEM), which is the best statistical multivariate model to analyse the effectiveness of interactions among latent variables. The CB-SEM is a combination of factor and path analysis, which, unlike the PLS-SEM method, aims at reproducing the theoretical covariance matrix without focusing on explained variance and with several restrictive assumptions (Hair et al. 2011). We also selected CB-SEM because the goal in this research is the comparison of alternative theories where we hypothesise circular relationships that require a global goodness-of-fit criterion.

To assure the validity of our model, we followed the recommended two-stage procedure as follows: in the first stage, the measurement model was estimated using confirmatory factor analysis to test the reliability and validity of the data; in the second stage, we identified the structural model that best fit the data and tested the supposed relationships among variables. Before analysing the data, we checked the survivorship bias in the sample by using the two-step procedure of Heckman (1976). We verified that survivorship bias is not a problem in the investigated model.

\section{Measurement model}

As a first step of measure validation, to assess the mono-dimensionality of the research constructs (Churchill 1979), we factor-analysed the final scales using the principal axis method, positing a single factor (exploratory factor analysis). After exploring the factor structure of the data, we submitted the data for confirmatory factor analysis. The results of this analysis verify that the measurement model performed well because the selected constructs demonstrate good internal consistency and reliability; the standardized factors are all above the recommended minimum of 0.40 , and the average variances extracted are all above the recommended minimum of 0.50 . All of our multiple-item constructs achieved Cronbach's alpha values of 0.71 or higher, indicating strong internal consistency, as a value $>0.60$ is considered a minimum acceptable value for factor loadings (Table 5). We examined each pair of constructs in our measurement model and found that they all demonstrate discriminant validity, as the variance extracted for the constructs was higher than the squared correlation between the constructs (Fornell and Larcker 1981). Convergent validity is also evident; positive 
correlations exist among the three social capital constructs (see Table 3), as is expected for constructs representing different dimensions of the same underlying concept.

As Table 6 shows, the overall fit of the measurement model is good; values close to or above 0.90 on the goodness-of-fit index and Bollen's incremental fit index (IFI) are desirable (Schumacker and Lomax 1996), and the recommended range for the normed chi-square statistic is between 1.0 and 2.0 (Hair et al. 1995). Thus, the results indicate that all of the constructs are adequate for use in the second stage.

\section{Nested model tests}

As the hypotheses involve the testing of mediation effects, a series of nested models were compared to select the one with the best fit. Nested model tests help to internally validate a hypothesised model by comparing the chi-squares of models that differ in the number of paths hypothesised; adding or deleting paths can derive nested models. A significant difference in the chi-square indicates that the more complex model provides a better fit to the data.

The four nested models are as follows: (1) a null model in which no relationships are assumed; (2) a saturated model, which consists of both the direct relationships among variables (social capital on innovation; knowledge acquisition on innovation) and indirect effects (social capital on innovation through knowledge acquisition); (3) the hypothesized mediation model, which considers only the indirect effects of social capital on innovation through knowledge acquisition; and (4) a direct model, which includes only the direct effects of social capital on product innovativeness (Table 6).

The nested model testing sequence and difference test verify that the hypothesized mediation model fit the data better than the saturated and direct models (Table 7). First, we compared the saturated model with the null model, verifying that the saturated model fit better than the null model. In the second step, we compared the hypothesis with the saturated model. As the difference in the chi-square was not significant, we recognised that the more parsimonious hypothesised model provided a better fit with the data. Finally, the comparison between the direct and saturated models produced a significant difference in the chi-square, indicating that the saturated model is preferred.

Table 6 Model Statistics (2018-2010)

\begin{tabular}{lrllllll}
\hline Models & Chi & p* & D.F. & GFI & IFI & NFI & $\begin{array}{l}\text { Normed } \\
\mathrm{Chi}^{2}\end{array}$ \\
\hline 1. Null Model & 1755.11 & $>0.00$ & 299 & 0.44 & 0.00 & 0.00 & 2.38 \\
2. Saturated Model & 280.10 & $>0.00$ & 162 & 0.87 & 0.91 & 0.83 & 1.68 \\
3. Hypothesized Model & 284.55 & $>0.00$ & 167 & 0.90 & 0.94 & 0.85 & 1.75 \\
4. Direct Model & 288.41 & $>0.00$ & 164 & 0.88 & 0.92 & 0.85 & 1.71 \\
\hline
\end{tabular}

Note: GFI: Jöreskog and Sörbom's goodness-of-fit index compares the predicted squared residuals with the obtained residuals, not adjusted for the degrees of freedom; IFI: Bollen's incremental fit index compares the proposed model to the null model, adjusted for the degrees of freedom; NFI: The Bentler-Bonett normed fit index compares the proposed model to the null model, not adjusted for the degrees of freedom; Normed chisquare: chi-square adjusted for the degrees of freedom

This table compares the most important variables of the different selected models 
Table 7 Model Test Sequence and Difference Test (2018-2010)

\begin{tabular}{lccll}
\hline Models & $\begin{array}{l}\mathbf{C h i}^{\mathbf{2}} \\
\mathbf{D i f f e r e n c e}\end{array}$ & D.F. Difference & $\mathbf{P}$ & Model Preference \\
\hline Saturated vs. Null & 1475.01 & 137 & $<0.005$ & Saturated \\
Hypothesized vs. Saturated & 4.45 & 5 & $>0.10$ & Hypothesized \\
Direct vs. Saturated & 8.31 & 2 & $<0.05$ & Saturated \\
\hline
\end{tabular}

This table shows the model test sequence with the difference test

Therefore, the results of the hypothesised model testing are reported in Table 8 .

\section{Hypothesis test}

Hypotheses 1, 2, and 3 propose that structural, relational, and cognitive social capital have a significantly positive association with knowledge acquisition. The results (Table 8) indicate that the standardized regression weights among structural embeddedness, relational embeddedness, and knowledge acquisition were significant $(p<0.01)$ and positive, with coefficients of $0.45,0.59$, and 0.42 , respectively. Thus, the first three hypotheses are confirmed. Hypothesis 4 concerns the relationship between knowledge acquisition and product innovativeness. The results indicate that the standardized regression weights between knowledge acquisition and product innovativeness were significant and positive, with a coefficient of $0.58(p<0.01)$. Therefore, H4 is supported. H5a suggests significant indirect effects of structural social capital on product innovativeness through knowledge acquisition. As predicted, the indirect paths through knowledge acquisition from structural social capital to product innovativeness $(\beta=0.38, p<0.01)$ were significant. As no direct effect was found for structural social capital on product innovativeness, the mediation model of knowledge acquisition provided support for Hypothesis 5a.

In a similar vein, the results disclosed no significant direct effect of relational social capital on product innovativeness, but relational social capital had indirect significant effects through knowledge acquisition on product innovativeness $(\beta=0.45)$. Thus, Hypothesis $5 \mathrm{~b}$ is supported. Similarly, cognitive social capital was shown to have no direct effect on product innovativeness, but it had an indirect effect $(\beta=0.49, p<0.01)$. In this way, Hypothesis $5 \mathrm{c}$ is supported. Finally, concerning the control variables, both product innovativeness and knowledge acquisition are positively linked to the BGs' total foreign sales, $\mathrm{R} \& \mathrm{D}$ spending, and interorganizational geographical proximity.

\section{Discussion}

The results of this study indicate that the evolution of social capital between BGs and their key foreign customers from the emergence to the early stage of a BG's lifecycle is positively related to knowledge acquisition and that knowledge acquisition influences the BG's innovation, as measured by the innovativeness of its products during the two analysed periods (Rowley et al. 2000). 
Table 8 Structural Equation Modelling Results (2018-2010)

Standardized P value Hypo-thesis

Estimate

\begin{tabular}{|c|c|c|c|}
\hline \multicolumn{4}{|l|}{ Direct Effects } \\
\hline $\begin{array}{l}\text { Evolution of Structural Social Capital on Product Innovativeness } \\
\text { Growth }\end{array}$ & 0.11 & n.s. & \\
\hline $\begin{array}{l}\text { Evolution of Relational Social Capital on Product Innovativeness } \\
\text { Growth }\end{array}$ & 0.01 & n.s. & \\
\hline $\begin{array}{l}\text { Evolution of Cognitive Social Capital on Product Innovativeness } \\
\text { Growth }\end{array}$ & 0.05 & n.s. & \\
\hline $\begin{array}{l}\text { Evolution of Structural Social Capital on Knowledge Acquisition } \\
\text { Growth }\end{array}$ & 0.45 & $<0.01$ & H1 \\
\hline $\begin{array}{l}\text { Evolution of Relational Social Capital on Knowledge Acquisition } \\
\text { Growth }\end{array}$ & 0.59 & $<0.01$ & $\mathrm{H} 2$ \\
\hline $\begin{array}{l}\text { Evolution of Cognitive Social Capital on Knowledge Acquisition } \\
\text { Growth }\end{array}$ & 0.42 & $<0.01$ & $\mathrm{H} 3$ \\
\hline $\begin{array}{l}\text { Evolution of Knowledge Acquisition on Product Innovativeness } \\
\text { Growth }\end{array}$ & 0.58 & $<0.01$ & $\mathrm{H} 4$ \\
\hline \multicolumn{4}{|l|}{ Mediation Effects } \\
\hline $\begin{array}{l}\text { Structural Social Capital on Product Innovativeness via } \\
\text { Knowledge Acquisition }\end{array}$ & 0.38 & $<0.01$ & $\mathrm{H} 5 \mathrm{a}$ \\
\hline $\begin{array}{l}\text { Relational Social Capital on Product Innovativeness via } \\
\text { Knowledge Acquisition }\end{array}$ & 0.45 & $<0.01$ & $\mathrm{H} 5 \mathrm{~b}$ \\
\hline $\begin{array}{l}\text { Cognitive Social Capital on Product Innovativeness via } \\
\text { Knowledge Acquisition }\end{array}$ & 0.49 & $<0.01$ & $\mathrm{H} 5 \mathrm{c}$ \\
\hline \multicolumn{4}{|l|}{ Control Variables } \\
\hline$\%$ of BGs' Foreign Sales on Sales on Knowledge Acquisition & 0.20 & n.s. & \\
\hline $\begin{array}{l}\% \text { of Foreign Sales with KFC on Total Foreign Sales on Product } \\
\text { Innovativeness }\end{array}$ & 0.05 & n.s. & \\
\hline BG’s R\&D on Knowledge Acquisition & 0.20 & $<0.01$ & \\
\hline BG's R\&D on Product Innovativeness & 0.37 & $<0.01$ & \\
\hline BG's Age at Internationalization on Knowledge Acquisition & 0.28 & n.s. & \\
\hline BG's Age at Internationalization on Product Innovativeness & 0.48 & n.s. & \\
\hline Geographical Proximity on Knowledge Acquisition & 0.45 & $<0.01$ & \\
\hline Geographical Proximity on Product Innovativeness & 0.55 & $<0.01$ & \\
\hline Cultural Proximity on Knowledge Acquisition & 0.67 & n.s. & \\
\hline Cultural Proximity on Product Innovativeness & 0.76 & n.s. & \\
\hline
\end{tabular}

This table shows the results of the structural equation model

First, our results, which introduce a dynamic perspective, contrast with the evidence of other studies on social capital and knowledge acquisition (i.e., Yli-Renko et al. 2001), which reveal a negative interaction between these two variables. In this study, both relational and cognitive social capital provide a positive and profitable mechanism to govern the relationship between a BG and its key foreign customers during its evolution throughout the lifecycle. Thus, the over-embeddedness argumentation (Uzzi 1997) does not seem to be valid here, and these results merit attention as related to a 
$\mathrm{BG}$, the internal nature of which is very different from traditional, older companies. At the same time, our results confirm the positive correlation between the evolution of structural social capital from the emergence to the early growth of a BG and the growth of knowledge acquisition during this period, suggesting that key customers may sustain knowledge acquisition abroad by providing introductions to other customers and their knowledge bases.

Finally, we receive support for the hypothesis that knowledge acquisition mediates the relationship between social capital and product innovativeness during the evolution of a BG from the emergence to the early stage of its lifecycle. From our dynamic perspective, social capital significantly predicts a firm's knowledge acquisition ability, which, in turn, is significantly associated with the innovativeness of newly developed products (Odorici and Presutti 2013). Thus, while the structural, social, and cognitive social capital in key customer relationships are unable to directly influence innovation activity in our field of research, the results highlight the essential role of knowledge as a key mechanism by which interorganizational foreign customers' collaborations can be leveraged by a BG during its lifecycle to reinforce its innovativeness. Thus, the quality of the relationship with key customers matters during the evolution of a BG (Bembom and Schwens 2018).

\section{Theoretical implications}

In this paper, following a dynamic temporal perspective of BGs' growth, we contribute to the international entrepreneurship literature concerning the influence of BGs' lifecycle on the interactions among social capital, innovation and knowledge acquisition (Covin and Slevin 1990; McCann 1991). In this regard, our results verify how social capital positively influences the product innovation process of BGs abroad by mediating the market and technological knowledge acquisition factor during their lifecycle, suggesting the possibility of investing in social capital as a durable and profitable resource to become more innovative abroad.

Our findings have several theoretical and managerial implications. First, from the literature on innovation inside domestic markets, we know that having strong relationships has a positive influence on innovation, but there is a risk that when the relationships become too strong, and when the network surrounding the firm has too many interconnected relationships, the firm may become over-embedded, and consequently, there is no supply or distribution of new knowledge. As we partly find that this is not the case for BGs, it could be that there is a significant difference between international and domestic relationships in this respect. Having international relationships characterized by strong social capital seems to be fruitful for learning and innovation, and the likelihood of over-embeddedness having a destructive effect on knowledge is lower for international relationships, as international innovation ventures are riskier and more uncertain than similar activities and processes in the domestic market. Are international relationships of a BG different? Yes, this could very much be the case. This study indicates that in an international context for a specific kind of small and innovative company such as a BG, having too few and too-strong relationships, which in turn have few links to other indirect relationships, do not harm learning and innovation.

Second, our findings confirm that BGs' innovation ability derives more from acquired market and technological knowledge in the interactions with key foreign 
customers than from the specific structural, relational, and cognitive characteristics of the social relationships. When a BG pulls its key foreign customers, which are distant from a geographical point of view, closer to its business connections, and consequently, to its technologies, products, and processes, it becomes more aware of innovation opportunities. Interaction in relationships with key foreign customers characterized by social capital entails openness and transparency between the supplier and the customer, which is conducive to the acquisition of knowledge. As most BGs are high-technology firms operating in markets characterized by long-term business relationships, the extent to which they acquire external knowledge is likely to enhance their ability to identify valuable knowledge and new ideas useful to improving product innovativeness. A BG can proactively develop relationships with key foreign customers beyond basic project networks, which may expand the scope of opportunity seeking (Coviello 2006) and problem solving to reinforce its product innovativeness.

Third, the focus in this study is not on customer relationships in general but on one specific relationship with key customers. By exploiting this specific relationship and involving the key customers - not any customer or all customers - in innovation activities, the BG can achieve breakthrough innovations characterized by novelty and creativity. Being strongly embedded in a key relationship is not a problem for learning, as long as the relationship, in turn, is interlinked to other firms, giving the BG a bridge to a supply of knowledge and information and a springboard to new contacts, orders, and potential relationships. Based on this finding, the question of when and how to involve other customers in the process follows, as the innovated products are going to be sold to and used by other customers as well. For BGs, this is a critical question, as customers might be located in different countries with different cultures and institutions, where, for instance, distribution systems and market preferences could be different compared to the context of a key customer relationship (Melén and Nordman 2009; Sasi and Arenius 2008).

The final conceptual implication originates from the complementarity of the social capital dimensions along the BGs' lifecycle. The results demonstrate that, first of all, having structural social capital in foreign relationships with key customers is a necessary condition during a BG's lifecycle to satisfy a minimum level of dependability and reliability before an emotional investment can be made in the relationships, as structural social capital is not sufficient to make a relationship efficient in the development of innovative products. During its lifecycle, the BG must invest in relational and cognitive social capital in the relationship to reduce the risks between two partners located in different countries. Relational and cognitive social capital reinforce trust and help in the development of common goals, norms, and reciprocal expectations concerning trust in the partner's goodwill and the overall trustworthiness of the partner. Therefore, conflict and coordination costs can be decreased. When this prevails, structural social capital can become beneficial for various learning activities. Structural social capital complements, rather than substitutes for, relational and cognitive social capital. The three dimensions of social capital complement each other in driving the acquisition of knowledge during the evolution of a BG's lifecycle. Relational and cognitive social capital must be close to over-embedded, but at the same time, it is crucial to have links to indirect relationships to other parts of the networks. To develop products characterized by novelty and creativity, which may change the industry, 
one needs to have structural social capital with some specific customers, which, in turn, can tap into resources and business with other partners.

\section{Managerial implications}

In addition to these theoretical arguments, a set of managerial implications arise from this study. We suggest that a BG should invest in social capital relationships with key customers during its lifecycle, as relationships of social capital provide access to resources and knowledge not otherwise available (Dhanaraj et al. 2004). This implies a need for competence to coordinate and utilize a set of interrelated cross-border relationships to derive value from a differentiated set of customer relationships (Hohenthal et al. 2014).

Furthermore, a durable investment in knowledge-exchanging relationships based on social capital can form the basis for profitable relationships that may eventually lead to even greater innovation opportunities (Hohenthal et al. 2014). This requires the management of an innovation process based on professional competences that is able to develop networks characterized by high social capital with a significant number of key foreign customers. If managers are to enjoy long-term success concerning international innovation in foreign markets, fostering their direct relationships may not be enough; they may also need to exploit the structural social capital and move beyond the BG's close networks. Hence, managers' ability to leverage external networks abroad can be considered a core competence.

Thus, a well-developed system of "pipelines" connecting the BGs to their key foreign customers, and beyond them, across the world, is beneficial for the knowledge acquisition of start-ups (Rowley et al. 2000), but knowledge flow through pipelines is not automatic, and participation in the networks is not free. Therefore, the process behind the creation and maintenance of global pipelines needs to be designed and planned in advance. This requires specific investments to ensure long and stable relationships.

The results indicate a need for policymakers to better address public policy to support the foreign innovation activity of BGs in the form of more tailormade policies and programmes related to their rapid international development (Agndal et al. 2008). This could allow a BG to better select foreign customers to reduce the risk of opportunism, which typically characterizes the relationships between distant partners. In fact, our results reinforce the necessity to better manage not only the tangible resources but also the BG's knowledge and networks, which are the intangible assets that allow a BG to accelerate its international growth.

\section{Limitations and future research}

Some limitations of our study must be discussed to pinpoint opportunities for further research. First, our results refer to BGs operating inside a high-tech cluster in Italy. To generalize our theory, a study involving other types of sectors should be performed, that is, with a sample of firms that are not necessarily highly technological or from a specific cluster. Moreover, future research should be conducted on BGs from other countries to enrich the empirical observations. Of course, this research is focused on a particular kind of firm, that is, a BG, and thus, the results must be interpreted in relation to this 
sample of small and innovative companies operating abroad since their emergence; future studies could enlarge these results to a more ample sample of wider firms.

Second, our definition of innovation aims to capture only product innovativeness, with no distinction between different types of innovation (i.e., disruptive, incremental or process innovation). Further research could try to develop this point by addressing the heterogeneity in innovation processes and extending this into other dimensions of business relationships to gain a more complete picture of the importance of the mediating role of knowledge acquisition.

In addition, the study does not analyse the efficiency of the innovation activities of BGs, as we have no information on the costs or resources utilized for this purpose, and it does not offer any knowledge about how the new products perform in the market, that is, whether the innovations can be defined as successful or not. Researchers could also include other significant boundary conditions that might influence the importance of both social capital and knowledge acquisition in the BGs' innovation processes inside foreign markets.

Moreover, this study relied on self-reported data from the BGs to measure social capital, knowledge acquisition, and product innovativeness, thereby creating the possibility of same-source bias. The data were collected at the BGs' offices; we did not collect data from the key customers who buy and use the developed products. In fact, due to the difficulty in measuring these concepts, we employed self-reported measures because of the potential for concept-specific accuracy and because of the unavailability of other measures across the entire sample. However, this is a common problem with cross-sectional designs (Yli-Renko et al. 2001).

Finally, we investigated the foreign relationships between a BG and its key foreign customers. Future research could broaden these results with an in-depth longitudinal analysis of the dyadic relationships between a BG and other business partners, such as suppliers and complementary firms, that is, by attempting to include other actors in the network in the analysis.

\section{References}

Adler, P. S., \& Kwon, S.-W. (2002). Social capital: Prospects for a new concept. The Academy of Management Review, 27(1), 17-40. https://doi.org/10.2307/4134367.

Ado, A., Su, Z., \& Wanjiru, R. (2017). Learning and knowledge transfer in Africa-China JVs: Interplay between informalities, culture, and social capital. Journal of International Management, 23(2), 166-179. https://doi.org/10.1016/j.intman.2016.11.003.

Agndal, H., Chetty, S., \& Wilson, H. (2008). Social capital dynamics and foreign market entry. International Business Review, 17(6), 663-675. https://doi.org/10.1016/j.ibusrev.2008.09.006.

Alguezaui, S., \& Filieri, R. (2010). Investigating the role of social capital in innovation: Sparse versus dense network. Journal of Knowledge Management, 14(6), 891-909. https://doi.org/10.1108 /13673271011084925.

Andersson, U., Dasí, À., Mudambi, R., \& Pedersen, T. (2016). Technology, innovation and knowledge: The importance of ideas and international connectivity. Journal of World Business, 51(1), 153-162. https://doi. org/10.1016/j.jwb.2015.08.017.

Hugo Baier-Fuentes, H., Merigó, J. M., Amorós, J. E., \& Gaviria-Mar, M. (2019). International entrepreneurship: A bibliometric overview. International Entrepreneurship and Management Journal, 15(2), 385429.

Baronchelli, G., \& Cassia, F. (2014). Exploring the antecedents of born-global companies' international development. International Entrepreneurship and Management Journal, 10(1), 67-79. 
Bell, J., McNaughton, R., \& Young, S. (2001). 'Born-again global' firms. Journal of International Management, 7(3), 173-189. https://doi.org/10.1016/s1075-4253(01)00043-6.

Bembom, M., \& Schwens, C. (2018). The role of networks in early internationalizing firms: A systematic review and future research agenda. European Management Journal, 36(6), 679-694. https://oi. org/10.1016/j.emj.2018.03.003.

Bika, Z., \& Kalantaridis, C. (2017). Organizational-social-capital, time and international family SMEs: An empirical study from the east of England. European Management Review, 159-178. https://doi. org/10.1111/emre.12160.

Boschma, R. (2005). Proximity and innovation: A critical assessment. Regional Studies, 39(1), 61-74. https://oi.org/10.1080/0034340052000320887.

Chen, H.-L., Hsu, W.-T., \& Chang, C.-Y. (2016). Independent directors' human and social capital, firm internationalization and performance implications: An integrated agency-resource dependence view. International Business Review, 25(4), 859-871. https://doi.org/10.1016/j.ibusrev.2015.10.010.

Churchill, G. A. (1979). A paradigm for developing better measures of marketing constructs. Journal of Marketing Research, 16(1), 64-73. https://doi.org/10.2307/3150876.

Cohen, W. M., \& Levinthal, D. A. (1990). Absorptive capacity: A new perspective on learning and innovation. Administrative Science Quarterly, 35(1), 128-152. https://doi.org/10.2307/2393553.

Coviello, N. E. (2006). The network dynamics of international new ventures. Journal of International Business Studies, 37(5), 713-731.

Coviello, N. E., \& Joseph, R. M. (2012). Creating major innovations with customers: Insights from small and young technology firms. Journal of Marketing, 76(6), 87-104. https://doi.org/10.1509/jm.10.0418.

Covin, J. G., \& Slevin, D. P. (1990). New venture strategic posture, structure, and performance: An industry life cycle analysis. Journal of Business Venturing, 5(2), 123-135. https://doi.org/10.1016/0883-9026(90 )90004-d.

D'Angelo, A., \& Presutti, M. (2019). SMEs international growth: The moderating role of experience on entrepreneurial and learning orientations. International Business Review, 28(3), 613-624. https://doi. org/10.1016/j.ibusrev.2018.12.006.

Deligianni, I., Voudouris, I., \& Lioukas, S. (2015). Growth paths of small technology firms: The effects of different knowledge types over time. Journal of World Business, 50(3), 491-504. https://doi.org/10.1016 j.jwb.2014.08.006.

Dhanaraj, C., Lyles, M. A., Steensma, H. K., \& Tihanyi, L. (2004). Managing tacit and explicit knowledge transfer in IJVs: The role of relational embeddedness and the impact on performance. Journal of International Business Studies, 35(5), 428-442. https://doi.org/10.1057/palgrave.jibs.8400098.

Eriksson, K., Johanson, J., Majkgård, A., \& Sharma, D. D. (1997). Experiential knowledge and costs in the internationalization process. Journal of International Business Studies, 28(2), 337-360. https://doi. org/10.1057/palgrave.jibs.8490104.

Falk, M., \& de Lemos, F. F. (2019). Complementarity of R\&D and productivity in SME export behavior. Journal of Business Research, 96, 157-168.

Fornell, C., \& Larcker, D. F. (1981). Evaluating structural equation models with unobservable variables and measurement error. Journal of Marketing Research, 18(1), 39-50. https://doi.org/10.1177 $/ 002224378101800104$.

Freeman, S., Edwards, R., \& Schroder, B. (2006). How smaller born-global firms use networks and alliances to overcome constraints to rapid internationalization. Journal of International Marketing, 14(3), 33-63. https://doi.org/10.1509/jimk.14.3.33.

Gabrielsson, M., Gabrielsson, P., \& Dimitratos, P. (2014). International entrepreneurial culture and growth of international new ventures. Management International Review, 54(4), 445-471. https://doi.org/10.1007 /s11575-014-0213-8.

García-Villaverde, P. M., Rodrigo-Alarcón, J., Parra-Requena, G., \& Ruiz-Ortega, M. J. (2018). Technological dynamism and entrepreneurial orientation: The heterogeneous effects of social capital. Journal of Business Research, 83, 51-64. https://doi.org/10.1016/j.jbusres.2017.10.004.

Hair, J. F., Ringle, C. M., \& Sarstedt, M. (2011). PLS-SEM: Indeed a silver bullet. Journal of Marketing Theory and Practice, 19(2), 139-151.

Hagedoorn, J. (2006). Understanding the cross-level embeddedness of interfirm partnership formation. Academy of Management Review, 31(3), 670-680. https://doi.org/10.5465/amr.2006.21318924.

Hair, J. F., Anderson, R. E., Tatham, R. L., \& Black, W. C. (1995). Multivariate data analysis with readings. Upper Saddle River, NJ: Prentice Hall.

Heckman, J. J. (1976) The common structure of statistical models of truncation, sample selection and limited dependent variables and a simple estimator for such models. Annals of Economic and Social Measurement, 5(4), 475-492. 
Hite, J. M. (2005). Evolutionary processes and paths of relationally embedded network ties in emerging entrepreneurial firms. Entrepreneurship Theory and Practice, 29(1), 113-144. https://doi.org/10.1111 j.1540-6520.2005.00072.x.

Hite, J. M., \& Hesterly, W. S. (2001). The evolution of firm networks: From emergence to early growth of the firm. Strategic Management Journal, 22(3), 275-286. https://doi.org/10.1002/smj.156.

Hohenthal, J., Johanson, J., \& Johanson, M. (2014). Network knowledge and business-relationship value in the foreign market. International Business Review, 23(1), 4-19. https://doi.org/10.1016/j. ibusrev.2013.08.002.

Iturrioz, C., Aragón, C., \& Narvaiza, L. (2015). How to foster shared innovation within SMEs' networks: Social capital and the role of intermediaries. European Management Journal, 33(2), 104-115. https://doi. org/10.1016/j.emj.2014.09.003.

Johanson, J., \& Vahlne, J.-E. (2003). Business relationship learning and commitment in the internationalization process. Journal of International Entrepreneurship, 1(1), 83-101. https://doi.org/10.1023 /A:1023219207042.

Johanson, J., \& Vahlne, J.-E. (2009). The Uppsala internationalization process model revisited: From liability of foreignness to liability of outsidership. Journal of International Business Studies, 40(9), 1411-1431. https://doi.org/10.1057/jibs.2009.24.

Kazanjian, R. K. (1988). Relation of dominant problems to stages growth in technology-based new ventures. Academy of Management Journal, 31(2), 257-279. https://doi.org/10.2307/256548.

Kim, D., Basu, C., Naidu, G. M., \& Cavusgil, E. (2011). The innovativeness of born-globals and customer orientation: Learning from Indian born-globals. Journal of Business Research, 64(8), 879-886. https://doi.org/10.1016/j.jbusres.2010.09.008.

Knight, G. A., \& Cavusgil, S. T. (2005). A taxonomy of born-global firms. MIR: Management International Review, 45(3), 15-35.

Kogut, B., \& Zander, U. (1992). Knowledge of the firm, combinative capabilities, and the replication of technology. Organization Science, 3(3), 383-397. https://doi.org/10.1287/orsc.3.3.383.

Larson, A. (1992). Network dyads in entrepreneurial settings: A study of the governance of exchange relationships. Administrative Science Quarterly, 37(1), 76-104. https://doi.org/10.2307/2393534.

McCann, J. E. (1991). Patterns of growth, competitive technology, and financial strategies in young ventures. Journal of Business Venturing, 6(3), 189-208. https://doi.org/10.1016/0883-9026(91)90009-3.

McGahan Anita, M., Argyres, N., \& Joel, A. C. B. (2004). Context, technology and strategy: Forging new perspectives on the industry life cycle. In A. C. B. Joel \& M. M. Anita (Eds.), Business strategy over the industry lifecycle (Vol. 21, pp. 1-21). Bingley: Emerald Group Publishing Limited.

Melén, S., \& Nordman, E. R. (2009). The internationalisation modes of born globals: A longitudinal study. European Management Journal, 27(4), 243-254. https://doi.org/10.1016/j.emj.2008.11.004.

Nahapiet, J., \& Ghoshal, S. (1998). Social capital, intellectual capital, and the organizational advantage. Academy of Management Review, 23(2), 242-266. https://doi.org/10.5465/amr.1998.533225.

Nieto, M., \& González-Álvarez, N. (2016). Social capital effects on the discovery and exploitation of entrepreneurial opportunities. International Entrepreneurship and Management Journal, 12(2), 507-530.

Nooteboom, B., Berger, H., \& Noorderhaven, N. G. (1997). Effects of trust and governance on relational risk. Academy of Management Journal, 40(2), 308-338. https://doi.org/10.2307/256885.

Odorici, V., \& Presutti, M. (2013). The entrepreneurial experience and strategic orientation of high-tech born global start-ups: An analysis of novice and habitual entrepreneurs. Journal of International Entrepreneurship, 11(3), 268-291. https://doi.org/10.1007/s10843-013-0112-2.

Oviatt, B. M., \& McDougall, P. P. (1994). Toward a theory of international new ventures. Journal of International Business Studies, 25(1), 45-64. https://doi.org/10.1057/palgrave.jibs.8490193.

Oviatt, B. M., \& McDougall, P. P. (2005). Defining international entrepreneurship and modeling the speed of internationalization. Entrepreneurship Theory and Practice, 29(5), 537-554. https://doi.org/10.1111 j.1540-6520.2005.00097.x.

Parra-Requena, G., Ruiz-Ortega, M. J., García-Villaverde, P. M., \& Rodrigo-Alarcón, J. (2015). The mediating role of knowledge acquisition on the relationship between external social capital and innovativeness. European Management Review, 12(3), 149-169. https://doi.org/10.1111/emre.12049.

Pérez-Luño, A., Medina, C. C., Lavado, A. C., \& Rodríguez, G. C. (2011). How social capital and knowledge affect innovation. Journal of Business Research, 64(12), 1369-1376. https://doi.org/10.1016/j. jbusres.2011.01.014.

Pirolo, L., \& Presutti, M. (2010). The impact of social capital on the start-ups' performance growth. Journal of Small Business Management, 48(2), 197-227. https://doi.org/10.1111/j.1540-627x.2010.00292.x. 
Prashantham, S., \& Birkinshaw, J. (2015). Choose your friends carefully: Home-country ties and new venture internationalization. Management International Review, 55(2), 207-234. https://doi.org/10.1007/s11575015-0244-9.

Presutti, M., \& Odorici, V. (2019). Linking entrepreneurial and market orientation to SMEs' performance growth: The moderating role of entrepreneurial experience and networks. International Entrepreneurship and Management Journal, 15(3), 697-720.

Presutti, M., Boari, C., \& Majocchi, A. (2011). The importance of proximity for the start-ups' knowledge acquisition and exploitation. Journal of Small Business Management, 49(3), 361-389. https://doi. org/10.1111/j.1540-627x.2011.00331.x.

Presutti, M., Boari, C., Majocchi, A., \& Molina-Morales, X. (2019). Distance to customers, absorptive capacity, and innovation in high-tech firms: The dark face of geographical proximity. Journal of Small Business Management, 57(2), 343-361. https://doi.org/10.1111/jsbm.12323.

Presutti, M., \& Boari, C. (2008). Space-related antecedents of social capital: Some empirical inquiries about the creation of new firms. International Entrepreneurship and Management Journal, 4, 217-234.

Rindfleisch, A., \& Moorman, C. (2001). The acquisition and utilization of information in new product alliances: A strength-of-ties perspective. Journal of Marketing, 65(2), 1-18. https://doi.org/10.1509 jjmkg.65.2.1.18253.

Rowley, T., Behrens, D., \& Krackhardt, D. (2000). Redundant governance structures: An analysis of structural and relational embeddedness in the steel and semiconductor industries. Strategic Management Journal, 21(3), 369-386. https://doi.org/10.1002/(sici)1097-0266(200003)21:3<369::aid-smj93>3.0.co;2-m.

Sasi, V., \& Arenius, P. (2008). International new ventures and social networks: Advantage or liability? European Management Journal, 26(6), 400-411.

Schumacker, R. E., \& Lomax, R. G. (1996). A beginners guide to structural equation modeling. Mahwah: Lawrence Erlbaum.

Shepherda, D. A., , Douglas, E. J., Shanleyc, M. (2000). New venture survival: Ignorance, external shocks, and risk reduction strategies. Journal of Business Venturing Volume, 15(5-6), 393-410.

Spector, P. E. (1987). Method variance as an artifact is self-reported affect and perceptions at work: Myth or significant problem? Journal of Applied Psy chology, 73, 443-483.

Starkey, K., \& Tempest, S. (2010). Bowling along: Strategic management and social capital. European Management Review, 1(1), 78-83.

Taylor, M., \& Jack, R. (2012). Understanding the pace, scale and pattern of firm internationalization: An extension of the 'born global' concept. International Small Business Journal: Researching Entrepreneurship, 31(6), 701-721. https://doi.org/10.1177/0266242611431992.

Tsai, W., \& Ghoshal, S. (1998). Social capital and value creation: The role of intrafirm networks. Academy of Management Journal, 41(4), 464-476. https://doi.org/10.2307/257085.

Uzzi, B. (1997). Social structure and competition in interfirm networks: The paradox of embeddedness. Administrative Science Quarterly, 42(1), 35-67. https://doi.org/10.2307/2393808.

Uzzi, B., \& Lancaster, R. (2003). Relational embeddedness and learning: The case of bank loan managers and their clients. Management Science, 49(4), 383-399. https://doi.org/10.1287/mnsc.49.4.383.14427.

von Hippel, E. (1988). The sources of innovation. Oxford: Oxford University Press.

Wagner JA, Crampton SM. 1993. Percent percept inflation in micro organizational research: An investi gation of prevalence and effect. Academy of man agement proceedings: 310-.

Wooldridge, J. M. (2006). Introductory econometrics: A modern approach. Mason: Thomson/South-Western.

Yli-Renko, H., Autio, E., \& Sapienza, H. J. (2001). Social capital, knowledge acquisition, and knowledge exploitation in young technology-based firms. Strategic Management Journal, 22(6-7), 587-613. https://doi.org/10.1002/smj.183.

Zahra, S. A., Ireland, R. D., \& Hitt, M. A. (2000). International expansion by new venture firms: International diversity, mode of market entry, technological learning, and performance. Academy of Management Journal, 43(5), 925-950. https://doi.org/10.2307/1556420.

Zahra, S. A., Ucbasaran, D., \& Newey, L. R. (2009). Social knowledge and SMEs' innovative gains from internationalization. European Management Review, 6(2), 81-93. https://doi.org/10.1057/emr.2009.6.

Zhao, H. (2015). Are social ties always valuable to knowledge search? Contextualizing knowledge search by foreign subsidiary executives in an emerging economy. Management International Review, 55(4), 511538. https://doi.org/10.1007/s11575-014-0234-3. 
Zhao, H., \& Hsu, C.-C. (2007). Social ties and foreign market entry: An empirical inquiry. Management International Review, 47(6), 815-844. https://doi.org/10.1007/s11575-007-0054-9.

Publisher's note Springer Nature remains neutral with regard to jurisdictional claims in published maps and institutional affiliations.

\section{Affiliations}

\section{Manuela Presutti $^{1} \cdot$ Giuseppe Cappiello $^{1} \cdot$ Martin Johanson $^{2,3,4}$}

1 Department of Management University of Bologna, School of Economics, Management and Statistics, School for Advanced Studies in Tourism Sciences, University of Bologna, Rimini Campus, 40126 Bologna, Italy

2 School of Technology and Business Studies, Dalarna University, 79188 Falun, Sweden

3 Department of Business, Economics and Law, Mid Sweden University, Sundsvall, Sweden

4 Department of Business Studies, Uppsala University, Uppsala, Sweden 